\title{
Efectivenes of online Transportation as a Means of General Transportation
}

\author{
Cucu Nurhayati ${ }^{1}$, Zulkifli $^{2}$, Lukman Hakim ${ }^{3}$ \\ \{cucu.nurhayati@uinjkt.ac.id ${ }^{1}$, zulkifli@uinjkt.ac.id², muhammadluqmanh@gmail.com ${ }^{3}$ \} \\ Universitas Islam Negeri Syarif Hidayatullah Jakarta, Indonesia ${ }^{1,2,3}$
}

\begin{abstract}
This article will discuss online transportation as a transportation option in the community. Online transportation is a choice because it is considered as a means of transportation that is fast, safe, and convenient. Castells thinking about networked society explains how to interact with people who rely heavily on the latest communication technology as a culture of real virtuality. Online transportation is becoming a new economic revival that gave birth to a networked society with an Informational, Global, and networked economy. Where the center of productivity lies in optimizing the combination of the use of production factors based on science and information. This study uses a qualitative approach to data collection techniques through observation, interviews, and document studies. The results of this study indicate that the use of online transportation is due to the relatively easy and flexible ordering process using a smart phone.
\end{abstract}

Keywords: Network society, online transportation, real virtuality

\section{Introduction}

In recent years the phenomenon of online transportation has emerged, namely private transportation that can be ordered by its users via smartphones. Gradually, the role of conventional motorcycle taxis began to be replaced by the presence of online transportation. Online transportation is the choice of consumers, because there is not yet adequate public transportation in terms of safety and comfort [1].

Online transportation, which is an alternative for people who want to use cheap and practical modes of transportation, is apparently in great demand [2]. Not without reason why many people are interested in using this online transportation service, we can place an order, find out the tariff that will be charged, and we can identify the driver that will take us so that we don't have to worry anymore about safety issues, and most importantly, we can place an order wherever and whenever because the order is made online.

The existence of this online transportation phenomenon can be considered as the impact of the development of communication and information technology in the community, where Manuel Castells said in his theory about networked society that the people in their daily lives were very dependent on communication technology [3].

Apart from the large number of people who switch to using online transportation services, their existence also raises the pros and cons. Even though its existence has been more than four years, it turns out that until now there has not been a clear legal umbrella for the existence of such online-based transportation. Especially for the type of two-wheeled vehicle, it is 
considered to be against the law because it is not in accordance with Ministerial Decree No. 35 of 2003 concerning the Implementation of Transportation of People on Public Roads, where there is no mention of motorcycles as one of the modes of mass transportation in Indonesia [4].

So whether the existence of online-based transportation as a result of the development of this communication technology will be able to overcome or at least reduce transportation problems among the people? Is this online transportation able to be the expected transportation?

Since the advent of online transportation, it turns out that many people have responded positively, as an alternative to transportation. In recent years online transportation services have become an alternative to conventional transportation options. Therefore, changes in alternative transportation as a result of technological developments are interesting to do research. This study aims to look at the role of online transportation in the community, by conducting a case study of University of Indonesia students living in the area near the entrance to KukelThis Word document can be used as a template for journal.

\section{Methodhology}

This study uses qualitative methods to obtain deeper data or information. This research is a case study of the role of online transportation for University of Indonesia students who live in areas near the entrance to Kukel in particular.

The determination of the informants was chosen by the researcher based on three criteria, the first being an online transportation driver (Gojek / Grab), the two parties providing online transportation services and the last being an online transportation user. The reason for choosing the informant is because these three criteria can provide information about the role of online transportation.

Based on this explanation, the composition of the informants that the researchers will meet are as follows, the informants that the researchers will meet as many as eight people with the criteria already mentioned, namely online transportation drivers, online transportation service providers, and online transportation users.

Of the eight informants, four of them are online transportation users, three of them are online transportation drivers, with a composition of two Grab drivers and one Gojek driver, and the last is from an online transportation service provider, namely from PT. Gojek Indonesia.

\section{The role of online transportation}

Online transportation, a type of mode of transportation that was born thanks to the rapid development of communication technology that makes it easy for people to get the ease of transportation is already available in various cities in Indonesia. Online transportation allows us to use its services whenever and wherever we want because of the sophistication of its technology, one of the advantages that people can feel when compared to using other conventional transportation services. Safety features are also offered by online transportation service providers, users can view information about the vehicle and the driver of the online transportation so that if there is something undesirable, the user can report the driver's identity 
to the authorities for follow-up. Certainly this will not be obtained when the public use urban transportation services (angkot) or conventional base taxi.

Online motorcycle taxis are widely used by students who need easy, safe, and convenient transportation. Online motorcycle taxi is very important in society that relies on technology in its activities to carry out daily activities, because online transportation drivers are considered to be more reliable than other conventional transportation drivers. Online transportation is considered quite easy to obtain, because only by using a smartphone, online transportation can meet the needs of the community wherever and whenever. This is certainly inseparable from the theory of network society Manuel Castells, who thinks that humans are in a network, connectivity between people with one another by utilizing advances in information and communication technology [3], as well as using smartphones, which until now it can help the community in carrying out their lives and can even be used for transportation.

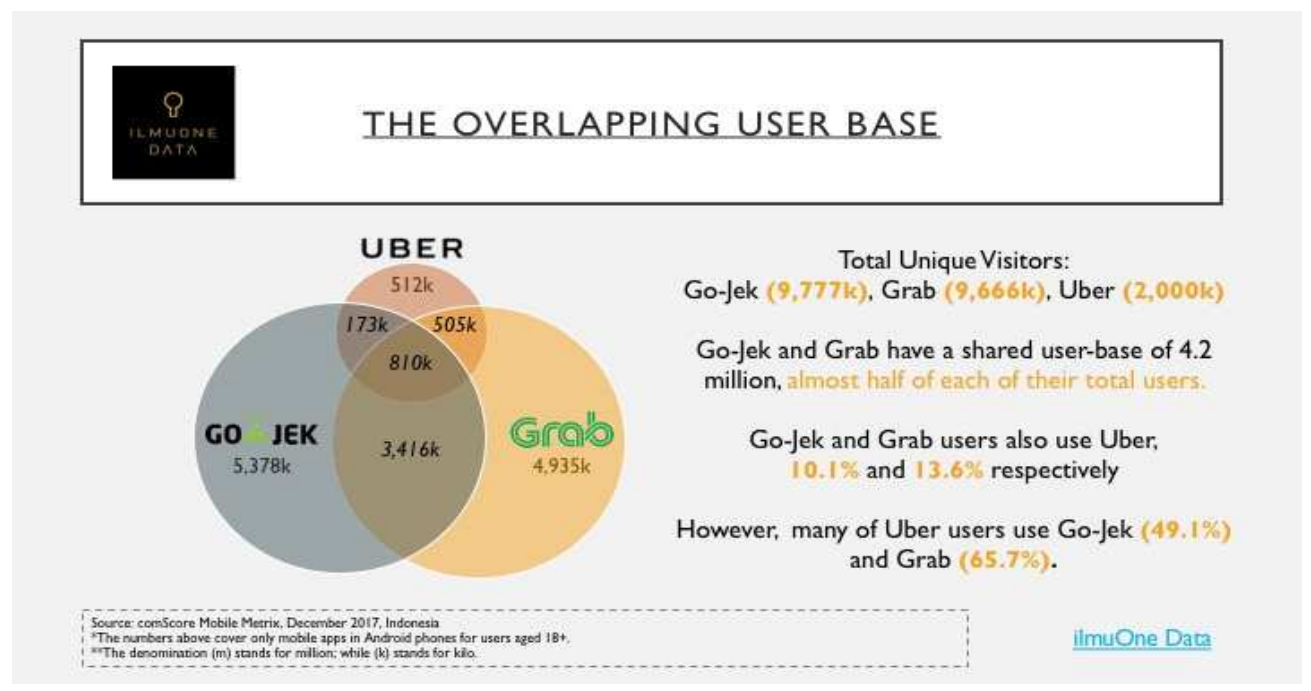

Fig 1. Number of online transportation users

The role of online transportation turns out not only to be felt by users of online transportation, but in addition to playing a role in providing transportation facilities that are easily accessible and accessible to all members of the community, it turns out that online transportation has also opened up new jobs for the community, not a few people who divert their jobs to become an online transportation driver, not a few people who make the job as an online transportation driver as a side job.

\subsection{Online Transportation as an Alternative to Transportation}

The emergence of online transportation in the community at this time was quite received positive responses from various walks of life. The public's need for fast, easy, and convenient transportation facilities can be realized by online transportation service providers. Although there was a time to get protests from some sections of the community but to date online transportation still shows its existence, even starting to spread evenly in cities throughout Indonesia. 
Especially for densely populated urban areas such as the capital city of Jakarta and surrounding cities such as Tangerang, Bekasi, Bogor and Depok, online transportation, especially online motorcycle taxi is very much needed considering the heavy traffic in these cities. Communities need fast transportation to break through heavy traffic to get to their destination. Online transportation has advantages over other conventional public transportation as well as in the case of flexibility. Besides being able to be ordered anytime and anywhere via smartphone, online transportation can also take passengers to places that cannot be reached by conventional public transportation.

Online transportation is widely used by UI students, especially those boarding in the western part of the campus because it is not affordable public transportation. Ojek pangkalan had become a mainstay for many years because the entrance to the UI campus in West Depok can only be passed by two-wheeled vehicles. Ojeg base does have the advantage of flexibility, because ojeg base can reach almost everywhere, but the tariff is sometimes less rational and poor service from ojeg base and the safety and comfort offered by online ojeg makes people prefer online ojeg. Online transportation can be used as a solution to transportation problems because it can provide cheap, fast and easy transportation, but on the other hand online transportation is considered not a solution because it is considered to increase air pollution, cause conflicts and increase the number of traffic accidents. In general, the presence of online transportation can be used as an alternative transportation that is quite good.

Although online transportation has been well received in the community, it does not mean online transportation has no shortcomings. Online transportation has led to conflicts with conventional transportation, resulting in a clash. Thus there should be government intervention to maximize the role of online transportation and to avoid conflicts with conventional transportation. The public wants this online transportation to still exist, and hopes that the government will really pay attention to the existence of online transportation. The government is expected to clarify the existing regulations so that in the future it will not cause conflicts with conventional transportation

\subsection{Online Transportation in Networking Communities}

Networking society, as explained by Manuel Castells, arises because of a new economic revival, its presence is inseparable from the convergence of various important events such as the information technology revolution, capitalism restructuring and statism [5]. The new economic power has informational, global, and networked characteristics. Castells called informational because Castells considered that the main source of productivity lies in optimizing the combination of knowledge and information based production factors.

If we look at the phenomenon of online transportation in this networking community, online transportation service providers really take advantage of advances in existing technology such as communication technology, by making an application that can be downloaded on smartphones. In networking communities, the use of smartphones is a must so that online transportation applications are easily accepted by the public.

In a networked society, there is a term that is put forward by Castells, namely the culture of Real Virtuality, in a networked society, the interactions between individuals is an interaction mediated by communication technology with the internet network or what we often say is interaction via a smartphone, whether it's through a chat application or social media. This certainly results in reduced direct interaction because the interaction that occurs is only through communication technologies such as smartphones, or what Castells call the term Space of flows, a new spatial form in the network society that shapes our social practices, 
where interaction which do not recognize geographical boundaries, so that they can communicate without having to face to face [6]. In this interaction, time is considered lost, or in the term Castells referred to as timeless time, because the public can communicate with anyone without being linked to time by the existence of communication technology. Changes in the pattern of interaction that makes it possible to make online transportation very easily accepted by the network community because of innovation that provides services via smartphones so that it can easily be adapted by the community.

In addition to the change in the way people do communication by using communication technology developments such as smartphones, which Castells call a real virtuality culture, in a networked society, information is open, we can find information very easily [5]. This has also been implemented by online transportation service providers, they make features for their users so that users can easily find the information they want when they want to use online transportation services, without having to meet drivers first and without having to take a long time.

Users can access information about travel fares, track the location of drivers in real-time, to access the identity of online transportation drivers who want to take them to their destination. This certainly makes the user feel safe and comfortable when traveling because if something unexpected happens in the trip, at least the users can easily report it to the authorities because they already have the identity of the driver who drove it.

By optimizing the factors of production based on science and information, online transportation has a significant role in a networked society, its presence can be easily adapted by people who are already dependent on advances in communication technology. Especially for UI Depok students who need transportation that is easily obtainable, considering that the location is indeed not passed by conventional public transportation such as public transportation so that the choice of transportation facilities to carry out daily mobility is very limited.

Online transportation is very easily accepted by the wider community, especially for students of UI Depok who do not have many transportation options because of its inaccessibility by conventional public transportation, the role of online motorcycle taxi is increasingly eroded the role of conventional motorcycle taxi over time, conventional motorcycle taxi income continues to decline, this explained by Castells who said that people who are unable to adapt by information technology will be excluded from the network so that it is considered not part of the network [6].

In a networked society, now the role of online transportation is very vital, reflecting from the informants obtained by researchers, almost all of them positively assess the existence of online transportation, although its existence also caused conflicts with conventional public transportation. The people are already very dependent on the advancement of communication technology so that they can easily accept the presence of online transportation.

In the general public, based on information obtained by researchers from informants, online transportation is seen as acting as a means of transportation that is easily obtained when we want to travel, online transportation is also considered to provide more features compared to conventional public transportation such as safety and comfort features that are more secure .

In addition, in a networked society, online transportation also plays a role in providing new jobs for people who find it difficult to find work or for people who want to earn extra income by becoming drivers of online transportation as a side job.

As Manuel Castells said about the theory of his network society, the network society arises because of a new economic awakening which is informational, global, and networked, an informational economy that means an economy whose source of productivity is highly 
dependent on science, information, and technology [5]. In this case the online transportation service providers master the things needed to be able to compete and survive in the network logic in networked society.

The role of online transportation for UI Depok students as explained in the previous subchapter is to become a means of transportation for the purposes of college assignments, a means of connecting transportation to other transportation, to become a reliable means of transportation in urgent situations.

In a networked society, online transportation can be said to be an alternative solution to the existing transportation problems among UI Depok students who live near the entrance to Kukel given the lack of transportation options available in the area. Online transportation is also considered to be able to provide a service advantage that is very easily adapted by the current network community because it has used the latest communication technology to facilitate its users, as well as for students of the University of Indonesia, Depok campus who are very adapting to the advancement of communication technology.

\section{Conclusion}

Online transportation has a significant role in society. Online transportation plays a role in providing a means of transportation that is fast, convenient, and safe, besides that online transportation also plays a role in providing new jobs for people who have difficulty finding work, and is also an alternative for people who want to supplement their income by making these jobs a side job.

By utilizing the latest technological developments, online transportation has succeeded in creating a means of transportation that is more practical than conventional transportation available, so that users, especially UI Depok students can make reservations very quickly when they want to travel, because online transportation can be ordered through the user's smartphone.

Online transportation provides more security features than other means of transportation in the form of information about the identity of the online transportation driver, the information will automatically appear on the smartphone of online transportation users. Online transportation also offers convenience features by providing online taxi facilities which are considered more convenient than other conventional public transportation facilities.

Apart from conflicts that have occurred due to the emergence of online transportation, online transportation still has an important role for the community, which requires a means of transportation that is easy, safe, and comfortable, so that online transportation still exists today. with all the technology it has, online transportation can still survive in society, and it can be said that online transportation is an alternative solution to transportation problems. Online transportation applies technology in accordance with the concept of the Manuel Castells network community which is highly dependent on communication technology.

Based on the results of the research and conclusions that have been presented by researchers, further research is suggested to study more deeply the concept of the Manuel Castells network community with this online transportation case study due to the lack of research on online transportation viewed from the standpoint of Sociology and network society theory.

The researcher's suggestion for the government is to pay attention to existing transportation facilities, both online and conventional so that they can walk side by side so that 
there are no more conflicts that have occurred before between online transportation and conventional transportation. The sustainability of online transportation must also be considered given that many people need transportation that is easily available in today's digital era.

\section{References}

[1] "Begini Persaingan Tiga Transportasi Online Terbesar di Indonesia Makin ketat," https://www.idntimes.com. [Online]. Available: https://www.idntimes.com.

[2] W. Aninditha, "Analisis Penerapan Teknologi Komunikasi Tepat Guna pada Bisnis Transportasi Ojek Online (Studi pada bisnis gojek dan Grab Bike dalam Penggunaan Teknologi Komunikasi Tepat Guna untuk Mengembangkan Bisnis Transportasi,” J. Ilmu Komun.

[3] M. Castells, The Network Society. Cheltenham: Edward Elgar Publishing Limited. Jakarta: Prenadamedia group, 2004.

[4] F. Rahman, "Kedudukan Hukum Usaha Ojek Online sebagai Angkutan Jalan di Jakarta: Studi pada PT Gojek Indonesia," Universitas Andalas. [Online]. Available: http://scholar.unand.ac.id.

[5] R. Sugiarti, Perkembangan Masyarakat Informasi dan Teori Sosial Kontemporer. Jakarta: Kencana Prenadamedia Group, 2014.

[6] F. K. Sujono, Manusia dalam Masyarakat Jejaring Telaah Filsafat Pemikiran Manuel Castells tentang Abad Informasi. Depok: Universitas Indonesia, 2013. 